\title{
Encouraging Society's Economy in Globalization Era : Traditional Markets in Napan Border Indonesia - Oecusse District (Timor Leste)
}

\author{
Eni Sugiarti, S.S., M. Hum. \\ \{eni-s@fib.unair.ac.id\} \\ Faculty of Humanities, Airlangga University Surabaya
}

\begin{abstract}
Markets at the border of Napan - Oecusse Timor Leste has a multifunctional state. Not only as a place for trading and transactions, but also a space where socio-cultural interaction occurs and the maintenance of social cultural values of the community as a cultural root happen. Political separation caused the emergence of new communication spaces in the form of markets to preserve the values that unite them. Other than that, the policy of developing nation's border gates is a threat to the sustainability of the market and its sociocultural function. The fundamental question in this research is how the implementation of the people's market in Napan as a place to meet economic needs and preserve the social cultural values of the border communities. The purpose of this study is analyzing the existence of markets and socio-economic functions by describing in a descriptive qualitative form from Kaplan.. The data was acquired through in-depth interview and observation, participation involved, and in-depth interviews of informants from Danny L. Jurgensen. The market at the border presents as a media to preserve the social and cultural values of the people who have the same cultural roots and to maintain the kinship of the indigenous people.
\end{abstract}

Keywords: People's market markets, indigenous peoples, national borders

\section{Introduction}

The cross-border market established by Indonesian and Timor-Leste government cannot yet function as a cross-country market that hold international trade law. Markets on the border of East Nusa Tenggara - Timor Leste. Market operations are carried out using traditional economic channels. Economic activities involving the people from the two countries are centered on traditional markets that are shared by border communities in both countries.

The emergence of the Napan border market cannot be separated from the political disintergation, cultural equality, easy access and geographic location that unites the people's economy in one region. The closeness of the border community with neighbor communities, which originally only as a family relationship which shares equality of socio-cultural values then shifted into economic relations. In this case it means that the intensity of interaction that is built is based on economic interests, but the basis of the activity is actually the equality of 
social and cultural values. Pasar Tradisional Bersama is the economic system which based on socio-cultural bond. North, Center, East and Oesilo-Oecusse area socio-culturally have a strong ethnic bond as Dawan ethnic, In the border are between Napan - Oecusse. there is market activity by activating the dynamic of Pasar Tradisional Bersama which seen as an effective tool to fulfill things and natural resources in both country. In some cases, like "cross boundary trade", are using different form, by activating traditional markets which seen as common thing. Because there are some factors which is required society around border area to do informal trade with different form of trade across border.

Based on the idea above, this research will focus on how form and activity of Pasar Tradisional Bersama in border area, and establishment socio-cultural values also the effect toward mobility in border area between Napan North Middle East district (Indonesia) and Oecusse district (Timor Leste). The aimed of the research is to describe forms and activities of Pasar Tradisional Bersama in the border area which is developed by economic base, in addition based on social values in those area. Explaining mobility in each country which happen as an effort to activate Pasar Tradisional in border area?

\section{Research Method}

The study of border areas can be carried out in various aspects including territorial, political, legal and security, welfare, social and economic aspects as well as other aspects [1]. Referring to what Wilson and Donnan said that the Border Region is an area that has very heterogenous and complex dynamics ... Borders we see the concluence of culture, power and state ... state act as aggregations of ruler for social and economic action ... in lives of border people of economiC value, whic are important to the daily function of the states in which they live [2] The method of this research is using qualitative approach because it could reveal the phenomenon about activity of Pasar Tradisional Bersama as a form of "cross boundary trade" which has informal characteristic from both different society and area. The phenomenon of traditional market as cross boundary trade activity which come from social values based on closeness cultural and emotional as Dawan people, investigated as natural economic activity that is doing by society from both country. By using qualitative approach, it will reveal the traditional market phenomenon, without it is limited by hypotheses which must be tested through statistic evidence. The qualitative descriptive approach in this study is used to explore and understand the meaning of individuals or groups in a social or humanity problem and try to resolve the complexity of a problem which is obtained through a method of inductive observation. According to Kaplan and Maner, emic and ethic approaches can be used in cultural research [3]. Emic approach in this study is used to collect the field data based on the direct findings according to the views of the local community. Meanwhile, ethic approach help to categorize cultural phenomena by referring to theories cultural change and cultural adaptation related.

The data were collected by observation which involved-participant [4][5]. Other than observation and involved-participant, the data collection was done through in-depth interviews with informants. The interview techniques from Scale is used in this study in Scale[6] , which include three steps; (a) Listening to stories,. (b) Paying attention to behavior (observing behavior). (c) Examines the historical footprint of research objects. The data were analysis with Socio-cultural relationship with the concept of social interaction [7] which is a relationship that is built between individuals, individuals with groups and groups with groups 
as a result of their fellow interactions. The market also becomes a public space where people from two countries gather and build social relations among them.

\section{Results And Discussion}

In connection with the conception of the boundary form and the traditional market activities together in the Napan border region with Oecusse emerged as a shared market. Underlying factors of the economy dynamics of the border region arise from multifactorial [8]. The market is formed as the center of the economy which is based on the similarity of the socio-cultural values of the people involved in it. The existence of markets has historically existed before the disintegration into two countries. The market then carries out the main supporting function in the people's economy in the border regions of the two countries.

Border market of Napan Bikomi North Middle East-Oesilo (Oecussee).

The existence of Napan market become border market is supported by geography location from North Bikomi which is located in high land. Napan market is strategic area because geographically Oecusse area border on Napan (isolated area). So, Napan market as a center of economic activity in boder market between Indonesia and Timor Leste.

Napan market is located in Napan village, north bikomi sub-district, North Middle East regency. The building stand over government's land on approval $R T / R W$. It high is on more than $500 \mathrm{~m}$ above sea surface. Napan market is built in 2004, the condition recently is broken because they've never renovated toward damage.

The existence of market didn't functioned as supposed to be by the traders and buyers could cause market condition damage. Society (seller and buyer) more choosing do their trade activity outside of market area along the streets near gate between Indonesia Oecusse. Across Indonesia area just limited by border line, there is border market named Oesilo which belong to Oecusse government. The condition of Oesilo market more bad because the market never been used in daily activity.

Traders who involve in market "street" activity of Napan come from Indonesia area, are local and nomad traders which sell goods from one market to another market. They come from Kefamenanu and other regency, they used to come at the time when "street" market Napan happen. Along Napan market street, there are many traders which sell their goods.

The involvement of Oecusse traders are not many as the beginning of Napan market. Early few years, the involvement of Oecusse traders decrease because of the economic fallacy and government's prohibition. The government of Timor Leste prohibit the society to do trade activity in border area near Indonesia. However, in certain time, especially when illegal traders time from Oecusse still face in Napan market.

Illegally, they do trade transaction. They sell sugar, rice, and coffee. Amount of goods from Oecusse that they sell just a little bit. It because when they bring the goods, they must through mouse way (narrow way which could be through by motorcycle or walk) at night or early morningnot worthy with the result or the profit that they got. Because they only sell a little bit goods, and cheap. If they took official way, they will lose out.

The existence seller and money changer service become usual in all border markets, including Napan street market. The money changer is always ready if there is person who want to change their dollar of America become rupiah of Indonesia. Most people see it will help a lot if there are visitors come from Oecusse, want to change America dollar by ratio of 1 dollar change with 10.000 rupiah. 
Beside transaction activity in border Napan, another activity which interest is gambling activity. Gambling activity is an activity which could be done by society of Timor Leste and Indonesia. According to some informant, one of the interesting point of market is to fulfill their daily necessity called gambling. Oesillo people like gambling, so, they come to the market to do gambling.

Socio-cultural function in border market

What is often overlooked in the study of the existence of traditional markets as an alternative to the malfunction of the official market on the border must also be seen in other dimensions. For instance, it can be seen from the socio-cultural dimension. The market is not only a meeting place between sellers and buyers, but it is developing its function as a place to meet families from different countries. Market days and territories have become the most eagerly awaited and utilized by all people of the two countries for economic transactions and social interaction. In the life of border communities, there are markers of cultural identity derived from religion, language, and customs. But in certain cases in the border area, there is a "gray area" where there are overlapping cultural markers. The difficulty with the presence of this gray area has been accompanied the formation process and identity [9].

Not only as place to do transaction and money changing, but also border market has sociocultural function as place to meet family between Indonesia and Timor Leste. Amount of hundreds Timor Leste people come to the market for shopping. Besides, they use the opportunity to meet their relatives. They meet up time held on as long as the market is open, around 09.00 Wita until $15.00 \mathrm{Wita}$. However, they still optimum their meet up time until the gate close, is around $18.00 \mathrm{WIT}$.

In the meet up time, they are going to have some family activity which center on ritual activity in custom house. The problem which discuss in the family meet up are having custom ritual and solving family problem or conflict. However, before having depth discussion about the problem, all of them have to eat sirih pinang and drink a bottle of sopi as a symbol togetherness and bond in a family. So, if they have family meet up time, they will prepare big dish to eat and the dish will bring by the member of the family when they back.

Be sides discussing custom house ritual planning and solving conflict problem appear in family, market time also use to help financial one another for family member of different country when the member need money. When market time, there are some family member who give money to other member of family which need the money.

Local language is a language for transaction in border market of North Middle East which is Dawan language.. The bond could make them as Dawan ethnic and they will feel the bond when they are using their mother tongue.. As the result, market become place where preservation of Dawan custom socio-culturally.

The existence of right official will guarantee owner right for sure, accelerate work contra solving, entrepreneur motivating, economical integrity, keeping macro economical stability, risk managing, supervising social safety, and pushing mechanism work of aspiration and accountability. Rodrik [10], Arvind Subramanian and Fransesco Trebby says that institutional has greater impact than geography location factor and economical openness toward income of a country [11]. Beside economical factor, institutional factor also get more attention from political factor perspective. Institutional could be understand as norm and social rule, either formal or informal which could build social relation, economic, politic also prop up various interaction among society elements [12]Service system in one system: Bea Cukai and immigration, but quarantine didn't belong to one system. [13] 


\section{Conclusion}

Markets in border North Middle East grow up become markets which had double functions: as place where transactions of seller and buyer including community of societies from both Indonesia and Timor Leste countries happened, and as tools for supporting sociocultural relationship. Those functions couldn't be separated historically of the existence markets in border areas that is continuing or changing of local markets because of politics factor. Economically, society ignore the function of the market, whether it is local market, or border market. For border society, they saw market economically as place where they could do transaction without tendency.

The daily in market become right place and time for most society to do social interaction and keep traditional values which market as place where families and relatives from separated country are met. Also, as tool for talking traditional values.

\section{References}

[1] R. Wadley, "Border Studies Beyond Indonesia Comparative Perspective," Antropol. Indones., vol. 26 , no. $67,2002$.

[2] H. Wilson, Thomas and Donnan, Border Identities, Nation and State at International Frontiers. Cambrige: Cambrige University Press, 1998.

[3] Kaplan, Teori Budaya. Yogyakarta: Pustaka Pelajar, 1999.

[4] D. L. Jongensen, Participant Observation , A MethodologyFor Human Studies Aplied Social Research Methods Series Volume 15. Newbury Park, London, New Delhi: Sage Publications, 1989.

[5] K. Saddhono, "Integrating Culture in Indonesian Language Learning for Foreign Speakers at Indonesian Universities,” J. Lang. Lit., vol. 6, no. 2, pp. 349-353, 2015.

[6] E. Sugiarti, "Dinamika Sosial Ekonomi di Perbatasan Indonesia-Timor Leste: Pasar Tradisional Bersama di Perbatasan Timor Tengah Utara -Oesilo Oecusse Timor Leste dan Mobilitas Sosial Masyarakat," Surabaya, 2016.

[7] S. Soekanto, Sosiologi Suatu Pengantar. Jakarta: PT Raja Grafindo Persada, 2002.

[8] M. Billa, "Faktor Penyebab Terjadinya Perdagangan Lintas Batas Pada Masyarakat di Perbatasan di Kabupaten Malinau Khusunya di Kecamatan Kayan Hulu dan Kayan Hilir,” Apl. Manaj., vol. 3 no3.

[9] B. (ed) Frederik, Ethnic Groups and Boundaries: The Soscial Organization of Culture Difference. Bergen-Oslo: University Forlaget-LOndon:George Allen \& Unwin, 2005.

[10] D. Rodrik, Economic Rules: The Right and Wrong of The Desmal Sciens. New York: WW.Norton Company, 2015.

[11] R. H. Leftwich, Economics of Social Issue. Chicago: Bussiness Publications, 2005.

[12] W. Brokensha, D.W. O.M. Warren and O, Indigenous Knowledge System and Develompment. Laham: University Press of America, 1980.

[13] E. Sugiarti, "Dinamika Sosial Budaya Masyarakat di Perbatasan Indonesia-Timor Leste: Kekerabatan dan Mobilitas," Surabaya, 2014. 